\title{
Pedagogical Strategies Used by English Teacher Educators to OVErcome the Challenges Posed by Emergency Remote Teaching During The COVid-19 Pandemic
}

\author{
ESTRATEgIAS PEDAGógICAS USADAS POR LOS FORMADORES DE DOCENTES DE INGLÉS \\ PARA SUPERAR los RetOS IMPUESTOS POR LA ENSEÑANZA REMOTA DE EMERgENCIA \\ DURANTE LA PANDEMIA COVID-19
}

STRATÉgies PÉdAgogiQues UTILISÉES PAR LES FORMATEURS D'ENSEIGNANTS D'ANGLAIS POUR RELEVER LES DÉFIS IMPOSÉS PAR L'ENSEIGNEMENT À DISTANCE EN SITUATION D'URgenCE PENDANT LA PANDÉMIE DE COVID-19

\author{
Jairo Enrique Castañeda-Trujillo \\ Assistant Professor, Universidad \\ Surcolombiana, Neiva, Colombia. \\ jairo.castaneda@usco.edu.co \\ http://orcid. \\ org/0000-0002-3002-7947
}

María Fernanda Jaime-Osorio Associate Professor, Universidad Surcolombiana, Neiva, Colombia. mariafernanda.jaime@usco.edu.co https://orcid. org/0000-0001-8938-8248

\begin{abstract}
The crisis in the education system generated by the appearance of CoviD-19 revealed the multiple gaps that exist due to the diversity of contexts to which students and teachers belong. This article reports on a case study which explored the challenges English teacher educators (TEs) at a public university in Neiva, Colombia faced during the pandemic due to the imposition of emergency remote teaching (ERT), the pedagogical strategies they used to respond to these challenges, and the ones that remain. To do this, data were collected from a questionnaire and a focus group with TEs and pre-service teachers (PSTS) from the language teacher education program. The main findings show that the transition from classroom teaching to ERT brought some challenges for TEs and their trainees related to the social realities existing in the context of the latter. To respond to these challenges, TEs had to adjust their teaching strategies and learn to use some technologies such as videoconferencing software and educational apps. Still some challenges remain for the future, such as enhancing PST's motivation, autonomy and classroom interaction. The study suggests the need to continue training language TEs on the use of ERT technologies and to find more and better ways to promote autonomous learning processes to adapt teaching practices to current times.
\end{abstract}

Keywords: COVID-19; emergency remote teaching; ICT; English teaching; teacher education; pedagogical strategies.

\footnotetext{
Received: 2021-03-01 / Accepted: 2021-06-23 / Published: 2021-09-11

https://doi.org/10.17533/udea.ikala/v26n3a12

Special issue on The Role of Technology in Language Teaching and Learning amid the Crisis Generated by the COVID-19 Pandemic. Editors: Marta González-Lloret, University of Hawai'i at Mānoa, usA; Laia Canals, Universitat Oberta de Catalunya, Spain; Jorge Pineda, Universidad de Antioquia, Colombia.

(C) 2021 Universidad de Antioquia. This is an open access article distributed under the terms of the Creative Commons License BY-NC-SA 4.0 International.
} 


\section{RESUMEN}

La crisis en el sistema educativo generada por la aparición del covid-19 puso de manifiesto las múltiples brechas que existen debido a la diversidad de contextos a los que pertenecen estudiantes y docentes. Este artículo informa sobre un estudio de caso que exploró los retos que enfrentaron los formadores de docentes de inglés de una universidad pública en Neiva, Colombia, durante la pandemia debido a la imposición de la enseñanza remota de emergencia, las estrategias pedagógicas que usaron para responder a estos retos y los retos que quedan por enfrentar. Para ello, recolectamos datos de un cuestionario y un grupo focal con docentes y estudiantes de un programa de formación de docentes. Los principales hallazgos muestran que la transición de la enseñanza presencial a la remota de emergencia trajo algunos desafíos para educadores y docentes en formación relacionados con las realidades sociales existentes en el contexto de los estudiantes. Para responder a estos desafíos, los formadores de docentes tuvieron que ajustar sus estrategias de enseñanza y aprender a utilizar algunas tecnologías, como el software de videoconferencia y las aplicaciones educativas. Aún quedan algunos desafíos para el futuro, como mejorar la motivación, la autonomía y la interacción en el aula de los docentes en formación. Las conclusiones apuntan a la necesidad de seguir formando a los docentes de idiomas en el uso de tecnologías de enseñanza remota de emergencia y de encontrar más y mejores formas de promover procesos de aprendizaje autónomo para adaptar las prácticas docentes a los tiempos actuales.

Palabras clave: COviD-19; enseñanza remota de emergencia; TIC; enseñanza de inglés; formación de docentes; estrategias pedagógicas.

\section{RÉSUMÉ}

La crise du système éducatif engendrée par l'apparition du COVID-19 a révélé les multiples lacunes qui existent en raison de la diversité des contextes d'où les élèves et les enseignants proviennent. Cet article rend compte d'une étude de cas qui a exploré les défis rencontrés par les formateurs d'enseignants d'anglais pendant la pandémie en raison de l'imposition de l'enseignement à distance d'urgence dans une université publique à Neiva, Colombie, les stratégies pédagogiques qu'ils ont utilisées pour répondre à ces défis et les défis qui restent à relever. Pour ce faire, nous avons collecté des données à partir d'un questionnaire et d'un groupe de discussion avec des professeurs et des étudiants d'un programme de formation de professeurs de langues. Les principaux résultats montrent que le passage de l'enseignement en classe au mode à distance en situation d'urgence a posé plusieurs défis aux enseignants et aux élèves en raison des réalités sociales existant dans le contexte des élèves. Pour relever ces défis, les formateurs d'enseignants ont dû ajuster leurs stratégies d'enseignement et apprendre à utiliser certaines technologies telles que les logiciels de vidéoconférence et les applications éducatives. Il reste encore des défis à relever pour l'avenir, tels que l'amélioration de la motivation, de l'autonomie et de l'interaction en classe des enseignants en formation. Les conclusions suggèrent la nécessité de continuer à former les professeurs de langues à l'utilisation des technologies d'enseignement à distance en situation d'urgence et de trouver des moyens plus nombreux et meilleurs de promouvoir des processus d'apprentissage autonomes pour adapter les pratiques d'enseignement à l'époque actuelle.

Mots clés : COVID-19; enseignement à distance en situation d'urgence; TIC; enseignement d'anglais ; formation des enseignants ; stratégies pédagogiques. 


\section{Introduction}

On December 31st, 2019, the world's citizens were officially informed of the first case of COviD-19 in Wuhan, China. By March 2020, while Europe, especially Italy and Spain, experienced rapid growth in deaths caused by the virus, Colombia reported its first case of coronavirus disease. The pandemic brought drastic changes and emergency responses from governments to control the high-speed spread of the virus and the increasing number of deaths. Some of the measures included the closure of schools and universities, quarantine periods, border closures, and restrictions on mass events.

Although the prospects generated by the pandemic seemed devastating for education, the National Ministry of Education of Colombia (known in Spanish as MEN) ordered schools to establish plans under provisional measures to ensure educational continuity. Faculty across the country agreed on a standard procedure for teaching their lessons remotely using information and communication technologies (ICT). In some ways this involved taking a leap of faith into the unknown for many with little digital skills or no technology access. In particular, the faculty from the Universidad Surcolombiana had two weeks to restructure the course syllabi and two more weeks to attend conferences and accelerated workshops on how to use ICTs for educational purposes. Indeed, many aspects were left behind in preparing teacher educators (TES) and pre-service teachers (PSTS) for virtual learning, teaching, and assessment.

As these conditions were favorable to look into undisclosed truths, we decided to answer the following research question: What are the pedagogical strategies and technological resources that English language TEs use to overcome the challenges posed by the transition from the classroom to emergency remote teaching in times of pandemic? The results show that TEs' awareness of PST's contexts increased, their strategies changed, and that they are still facing challenges regarding knowledge and use of technological tools and the promotion of autonomous learning. Thus, this article presents a profound reflection on the case of a language teacher program providing emergency response to the pandemic in a public university in Colombia.

\section{Theoretical Framework}

This research study is based on sociocultural theories regarding emergency remote teaching, ICTs in education and English language teaching, and teachers' pedagogical practices.

\section{COVID-19 and Emergency Remote Teaching}

Several authors have agreed upon the term Emergency Remote Teaching (ERT) to describe the temporary shift from face-to-face instruction to a virtual mode due to a crisis such as the one provoked by Covid-19 (Bozkurt \& Sharma, 2020; Golden, 2020; Hodges et al., 2020; Mae-Toquero, 2021; Olasile Babatunde \& Emrah, 2020; Vlachopoulos, 2020). Hodges et al. (2020) prevent us from confusing ERT with online learning. The authors state that ERT's main objective "is not to re-create a robust educational ecosystem but rather to provide temporary access to instruction and instructional supports in a manner that is quick to set up and is reliably available during an emergency or crisis" (para. 13). According to Mae-Toquero (2021), ERT might offer practical but unreliable access for learning to continue. Despite not being as refined as online education, it presents itself as challenging to guarantee quality education, especially for institutions in countries that never transitioned to distance education delivery.

Barbour et al. (2020) are probably the most fervent group of scholars that propose a thorough reflection on the differences between online teaching and emergency remote teaching. They establish as the main differences the time for planning, preparation, and development. Regarding time for planning, the authors set three to six months for online learning and just a few weeks for emergency remote teaching. Moreover, they contend that:

many of the online learning experiences that teachers will be able to offer their pre-service teachers will 
not be fully featured or necessarily well planned, and there's a high probability for suboptimal implementation. We need to recognize that everyone will be doing the best they can, trying to take just the essentials with them as they make a mad dash during the emergency. Thus, the distinction is important between the normal, everyday type of effective online instruction and that which we are doing in a hurry with bare minimum resources and scant time: emergency remote teaching. (Barbour et al., 2020, p. 6)

Bozkurt and Sharma (2020) also call researchers to pay conscious and careful attention to the use of the terms distance education and remote education, since any omission in this explanation can cause long-term consequences that would lead to unfair comparisons. For the authors,

distance education is characterized by the distance in time and/or space between learners and learning resources. While remote education refers to spatial distance, distance education considers distance within the perspective of different angles and strives to explain it through transactional distance”. (Bozkurt \& Sharma, 2020, p. ii)

Although distance is presented as a confusing term here, we should interpret it as either just spatial distance (common in remote learning) or transactional distance, which is provoked by the lack of rapport, communication, or autonomy among the actors: teachers and students.

All in all, we understand that distance education and especially online education differ dramatically from ERT. In fact, ERT should be understood as the first attempt to do online teaching without adequate time and preparation due to the unexpected and drastic changes in the circumstances of the educational modality. After the first attempt, ERT can evolve to distance and even online teaching as long as the planning, execution, and evaluation conditions return to what was considered the usual teaching conditions.

\section{ICT in Education and English Language Teaching}

ICTs have been defined as a "diverse set of technological tools and resources used to communicate, and to create, disseminate, store, and manage information" (Burton, 2002, n.p.). Sarkar (2012) explains that they "consist of the hardware, software, networks, and media for collection, storage, processing, transmission and presentation of information (voice, data, text, images), as well as related services" (p. 32). The author classifies ICTs into two components: (a) infrastructure, which refers to the physical telecommunications systems, and networks and the services that utilize those; and (b) technology, which refers to the hardware and software of information collection, storage, processing, and presentation (Sarkar, 2012, p. 32). ICT use makes it possible to extend educational opportunities because they transcend in time and space.

In terms of computer use in education (one of the most used devices in education), ICTs date back to the late 60 s and 70 s when computers were first used to deliver material for students to practice the language through drill repetition (Tafazoli \& Golshan, 2014). Many authors have classified the development of the gradual use of computers for educational purposes under three distinct phases: Behavioristic CALL (Computer Assisted Language Learning), Communicative CALL, and Integrative CALl (Barson \& Debski, 1996; Warschauer, 1996; Warschauer \& Healey, 1998, Warschauer, 2000). Although there was no consensus about the times in which each one of them took place, the authors agreed upon their main characteristics. For example, the behavioristic phase is related to the use of computers under a grammar-translation and audiolingual approach. Its main purpose was to drill and practice because it was focused on accuracy. The Communicative CALL phase emerged from the change to a cognitive paradigm in language; therefore, personal computers' main objective became accuracy and fluency. Finally, the Integrative CALL phase included multimedia and internet use as well as a shift to a socio-cognitive view on language because the focus was to provide students a space to exert their agency.

Bax (2003) contested Warschauer's phases by pointing out some inconsistencies in time and 
definitions as well as proposing different terms for each of them: Restricted, open, and integrated CALL. The author mentions that restricted CALL refers to the software, activity types, teachers' role, and feedback, and other restricted dimensions; for the author, even if they were all 'relatively restricted,' they were not all behaviorists. All the same, the term Open CALL refers to a more open approach to the previous dimensions. He presents Integrated CALL as a key point that differs from Waschauer's phase because the author acknowledges its lack of completion to a significant degree. To conclude, Bax argued that the future of CALL depended on the progression from Open CALL to Integrated CALL.

Chambers and Bax (2006) proposed that CALL practitioners should work towards a state of 'normalization' that was understood as:

when computers (...) are used every day by language students and teachers as an integral part of every lesson, like a pen or a book ... without fear or inhibition, and equally without an exaggerated respect for what they can do. They will not be the centre of any lesson, but they will play a part in almost all. They will be completely integrated into all other aspects of classroom life, alongside coursebooks, teachers and notepads. They will go almost unnoticed. (Bax, 2003, p. 23)

Chambers and Bax list four factors that may hinder CALL normalization and effectiveness: Logistics (facilities should be not placed outside the "normal" classroom); stakeholder's conceptions, knowledge, and abilities (to feel confident enough to use computers, they need to have enough knowledge of and ability with them); syllabus and software integration (CALL should be integrated into the syllabus; teachers should be allowed the use of 'authorable' materials); and training development and support (best if offered in collaborative mode). Back in 2006, the authors did not count on a pandemic to accelerate the process of normalization, nor did they conceive that the virus causing the pandemic would make those factors' effects more evident than ever.

\section{Teachers' Pedagogical Practices}

For the purposes of this study, pedagogical practices will be defined as "a dialectic interaction between the English language teacher and the sociocultural and educational setting which permeates the roles he or she [the teacher] is expected to play in the language classroom" (Insuasty \& Jaime-Osorio, 2020, p. 67). Pedagogical practices are also a social, objective, and intentional praxis (Fierro et al., 1999) or, as Huberman (1999) defined them,

\section{A conscious, deliberate, and participatory process im- plemented by an educational system or an organization to enhance performances and results, encourage the development for the renewal in academic, professional, and labor fields and to cultivate the spirit of commit- ment of each person with society, especially with the community in which he or she is immersed. (p. 25)}

As an interaction or a process, pedagogical practices can be transformed. Their character and the influence of the many factors that surround teachers' decision-making processes can affect teachers' actions before, during, or after implementing their lessons. Teachers' behavior can be better explained by the metaphor of an iceberg (Malderez \& Bodóczky, 1999), whose tip is what we see in a classroom. Below the water's surface, there is planning and reviewing, selecting, and learning. At a deeper level, teachers' behavior is affected by the knowledge of their pupils, language form and use, activities, and process skills, as well as conceptualizations of education, teaching, learning, professionalism, language teaching, language, language policy. In times like these, experience also plays a significant role. So, considering the pandemic forced teachers to experience a drastic change in educational conditions, their teaching practices were transformed as well.

\section{Method}

As this study intends to explore the pedagogical strategies and technological resources used by English TEs to overcome the challenges posed by the transition from face-to-face to ERT in pandemic times, we decided to use a qualitative approach to research. Qualitative research pursues examining thoroughly the experiences people live 
in different contexts (Kincheloe, 2003; Merriam \& Tisdell, 2016). During the transition to ERT, the English TE's experiences constitute part of the social construction of realities that are susceptible to being interpreted and understood through qualitative research (Flick, 2009; Merriam \& Tisdell, 2016). Additionally, qualitative research allows interpreting these experiences from a subjective perspective without ignoring the research rigor and trustworthiness. As researchers, we are committed to linking the experience with each participant's personal view, acknowledging them as those who know and not focusing only on what they know (Vasilachis de Gialdino, 2009).

This research is part of an exploratory case study that attempted to comprehensively analyze the challenges faced by English TEs using new strategies and technological devices that emerged during this time and have not been seen in context (Duff, 2008). According to Yin (2002), a case study is a "contemporary phenomenon within real-life context" (p. 1). It is composed of a particularity (changes caused by confinement), a contextualization (ELT program at a public university in Neiva, Huila, Colombia), and interpretation (researchers analyzing the phenomenon experienced).

The ELT program within which the study took place aims to educate pre-service English language teachers to work in rural or urban schools in the region. Within its curriculum, three components contribute to achieving that: Specific disciplinary knowledge, didactics of the discipline, and pedagogy. The program is $100 \%$ face-to-face, but during the mandatory confinement all classes were held remotely. This dramatic change resulted in an interruption of the processes that were taking place within each class. Additionally, some PST had problems due to a lack of technological resources or connectivity that led them to make some unfortunate decisions, such as dropping out of some classes. However, classes continued to develop until the semester ended on September 5, 2020; then, the collection of information for this study began.

\section{Participants}

The participants in this study were 11 full-time and four part-time TEs. Four of them have completed their doctoral degrees, while the other 11 have their master's degrees (see Table 1). Furthermore, three of these educators had been working in the ELT program for about 30 years, four of them had more than ten years, and the other eight had been in the program for 4 to 7 years. The program instructors were there throughout the transition process from face-to-face to ERT. They had to reorganize the academic spaces and adapt them to the PST's current needs. This activity demanded many hours of work and constant meetings to come to agreements that would benefit the trainees without sacrificing the academic content or the quality of the educational processes.

Participants also included, 26 teachers in preparation -19 women and 7 men - who voluntarily answered a questionnaire and took part in the focus group organized by the direction of the program. They were enrolled in separate semesters, ensuring that the study had broad coverage. Thus, four of them were in the fifth semester, seven in the sixth, four in the seventh, four in the eighth, six in the ninth semester (Table 1). Moreover, some live in the city $(77 \%)$, where conditions are different from those in small distant towns (66\%).

\section{Data Collection}

As mentioned above, data collection took place after the end of the academic semester. Two questionnaires were used to collect data: one for TES and one for PSTS. These instruments contained questions designed to get information about TEs' strategies and the changes that emerged from the transition to ERT. The first questionnaire, answered by TEs, looked into the strategies and virtual resources they used during the ERT mode and their evaluation of such strategies and resources. It also intended to examine the classes' interaction and mediation while using such strategies. The second questionnaire, applied to PST, was 
Table 1 Participants' profiles

\begin{tabular}{lllc}
\hline \multicolumn{1}{c}{ Type } & Association & \multicolumn{1}{c}{ Education } & Count \\
\hline \multirow{2}{*}{ In-service } & Part-time & Magister & 4 \\
teachers & Full-time & Magister & 7 \\
& Full-time & Ph.D. & 4 \\
\hline \multirow{4}{*}{ Pre- } & Student & Fifth semester & 4 \\
service & Student & Sixth semester & 7 \\
teachers & Student & Seventh semester & 4 \\
& Student & Eighth semester & 4 \\
& Student & Ninth semester & 6 \\
\hline
\end{tabular}

focused on getting insights about the TEs' use of strategies and the possible changes they could perceive in this process. Additionally, a focus group with both groups of teachers was conducted via Google Meet ${ }^{\circ}$. The main goal of this was to hold a dialogue with them about the experiences of the former and the perspectives of the latter.

\section{Data Analysis}

For this case study, we decided to use grounded theory as a method to analyze data. Following the guidelines of grounded theory, the data are subjected to repetitive inspection, coding, and categorization according to their recurrence level and saturation (Glasser \& Strauss, 1967, cited in Merriam \& Tisdell, 2016). We used Atlas.ti software to organize the questionnaire responses and the focus group transcription and to conduct the open, axial, and selective coding, as proposed by grounded theory. As a result, three core categories connected to this study's main objective emerged: what the pandemic and confinement brought to initial education, changes in the strategies used in classes, and challenges that remain for the future.

\section{Findings}

As the main objective of this case study was to explore the pedagogical strategies and technological resources used by English TEs to overcome the challenges posed by the transition from classroom teaching to ERT in pandemic times, we decided to present the results in the following order: First, we describe the new challenges and difficulties brought by the ERT modality. Subsequently, we present the changes in the strategies used by English TEs during the transition from classroom to ERT mode. Finally, we highlight the future challenges that this experience leaves from the perspective of both groups of teachers.

\section{What the Pandemic and Lockdown Brought to Initial Education}

This first category attempts to provide an overview of the challenges that English TEs encountered during the transition to the ERT mode. The first challenge that these teachers faced in this transition was becoming aware of the PSTs' particular circumstances. Before mandatory confinement, these teachers' realities were not relevant or visible when both groups of teachers met in the classroom. This lack of relevance was due to the fact that TEs could not perceive the difficulties that affected the trainees in their classes. When moving to the ERT mode, the walls that delimited the classroom disappeared, making visible some of the circumstances and particular dynamics that the trainees were undergoing in their homes, as expressed by an English teacher educator:

\section{The only thing that I highlight as unfavorable is when there is some interruption due to some situation at home, especially by the children. These situations cause a loss of concentration, and pre-service teachers can not follow the thread of the class. Also, the fail- ures on occasions of the technological equipment and the Internet connection. ${ }^{1}$ (First questionnaire, TE 5 , October 13, 2020).}

Trainees also contributed to the understanding of this first challenge, as it is shown in the next extract from the focus group:

One pre-service teacher spoke on behalf of those who did not communicate with teachers. He stated that

1 The instruments were answered in Spanish, the researchers translated all the quotes literally. 
some of his classmates did not attend due to particular family situations that triggered their economic or psychological instability and led to some apparent disinterest among pre-service teachers in virtual meetings. (Focus group, TE2, September 29, 2020)

The dynamics reported here by the English teacher educator and her/his? pupil reflects the reality of many trainees in the program. First, the lack of dedicated spaces to attend classes from home and the family dynamics made it difficult for many trainees to concentrate. For many of them, it was not easy to find a private place to attend their classes, either because they lived with their siblings or other relatives who also took classes or worked remotely, or because they lived in small houses or rural areas. Secondly, the pandemic and confinement resulted in economic hardship for families. Many people lost their jobs, including some of the trainees, who had to support their parents and relatives.

Each of us lives in different circumstances and environments. It is one thing to be in the classroom where there are less than 20 students and the teacher, and another is to be at home, with family, siblings, and the difficult economic situation caused by covid. (Questionnaire, PST 15, January 29, 2021)

Thirdly, some of the trainees came from nearby towns or regions, therefore they had to travel long distances to go to the university. When the pandemic was declared, they were suddenly forced to return to their places of origin where connectivity conditions were precarious.

Due to confinement restrictions, I returned to Rivera (a town near Neiva), where the Internet signal is terrible, and the family situation is worse. (Questionnaire, PST22, February 4, 2021)

I live on a farm, and when it rains, the Internet crashes, which affected my performance in my classes. (Questionnaire, PsT 18, February 2, 2021)

Besides, many of them used technological devices (personal computers or laptops) granted by the university. However, being outside campus, it was essential for them to buy their own equipment, which was unaffordable for some.
I know that many families share a cell phone with four children and that often there is no computer at home or connectivity is poor. (Questionnaire, PST15, January 29, 2021)

Lastly, this pandemic situation changed everyone's life, and this brought about psychological consequences for many. These were some of the realities PSTs had to endure during the transition; possibly, there were many others that we could not account for in this paper. Their situations mirrored those of many other students across the country, or even in the world.

And the TE stated: It was the confirmation of the social gaps that exist and how we teachers should look for ways to promote inclusive learning environments. (Second questionnaire, TE7, February 10, 2021). Therefore, English TEs found themselves in the need to become aware of those issues and consider them when planning their classes.

Other educators added,

I learned that in our context, we were not yet ready to transition that quickly. Circumstances forced us to do so, but many teachers and students had difficulties accessing and using these technologies. (Second questionnaire, TE4, February 10, 2021).

Sometimes we are not aware of the reality of our students or the effort they make. (Second questionnaire, TE2, February 2, 2021).

One of the great takeaways this experience has brought with it is that neither the institutions nor the English TEs can take it for granted that their pupils have all the resources at hand to learn from home. Thus, empathy became essential during these critical times, as noted by one of the TEs:

\footnotetext{
After applying a questionnaire to her students, the teacher highlights the teachers' empathy towards her students. This empathy was expressed in the teacher's understanding and sensitivity to the demanding situations students went through (problems of a personal nature, attitude, connection, etc.). (Focus group, Teacher 1, September 29, 2020)
}

A PST during the focus group assures something similar: 
One of the students claims that the teachers took the time and paid attention to each student despite the situation, which is something to note. (Focus group, Teacher 5, September 29, 2020)

Although English TEs' empathy was present in the transition from face-to-face to ERT mode, class dynamics were affected in terms of interaction. These changes in interaction among and PST became the second challenge. As an English TE explained:

The interaction was notably affected, especially between students and students' low participation in the two courses. (First questionnaire, TE4, October 13, 2020).

Interaction is a fundamental part of classes, especially those aimed at learning the language or those related to pedagogical foundations. However, due to the realities explained in the first challenge, this interaction was significantly reduced. Some of the trainees saw it this way:

Once homeschooling started, I feel like most teachers tried to adapt quickly. However, there was no good teacher-student connection initially, and there were difficulties in terms of class agreements. (Questionnaire, PST6, January 27, 2021).

Presentations were frequent. I think it happened as a way of "interacting" since the students had little participation when the teacher spoke. (Questionnaire, PST4, January 27, 2021).

Despite their best efforts, interaction was still a big problem within the class dynamics. This situation caused adverse feelings in the English TEs, as shown below:

The saddest thing for me has been not knowing my students, that if I see them on the street, I will not recognize them. That human part is invaluable, and that has not happened in this modality. (First questionnaire, TE2, October 13, 2020)

Suddenly, we find ourselves trying to develop classes in front of a screen without receiving any kind of feedback from the students. It gets frustrating. (First questionnaire, TE1, October 13, 2020).

In these comments, English TEs state that they have experienced some negative feelings such as sadness and frustration. These emotions reflect how bad they felt for not being able to interact with their students. It was not merely due to having them face-to-face to instruct them, but to strengthen the interpersonal relationships that contribute to the community of practice construction.

Consequently, this new reality brought a feeling of helplessness. English TEs stated their intention to contribute to improving interactions; although, given the circumstances, it was impossible for some of them:

Although I have sometimes tried to get them to turn on their cameras, it is impossible because the Internet is failing, or they use it as an excuse to not be seen. (First questionnaire, TE2, October 13, 2020)

Many students also claimed not to be able to participate in the sessions due to connectivity problems. However, due to the restrictions imposed by isolation and strict quarantine, not much could be done. (First questionnaire, TE1, October 13, 2021).

This constant concern of improving interaction has been coupled with issues associated with the constant use of technology. For some of them, being in front of a computer and using programs or web pages has been a huge challenge.

Although many English TEs had already included some other technological tool or other digital resources in their classes, the sudden change in circumstances made many of them realize that they were not really prepared to teach under the ERT modality. This third challenge is manifested as follows:

I learned that in our context, we were not yet ready for such a rapid transition. Circumstances forced us to do so, but I think that many teachers and students had difficulties accessing and using these technologies. (First questionnaire, TE3, October 13, 2020).

He wasn't ready for the transition, and actually, I don't think he's used to it yet. Sitting in front of a computer for more than two hours has been difficult to handle. (Questionnaire, PsT11, January 27, 2021)

I was not prepared, nor do I want to be prepared, since I do not see myself in the world of virtual education. 
I feel that I do not learn the same way, nor do I have enough motivation, since the environment often does not help. (Questionnaire, PST8, January 27, 2021)

As this English TEs and these trainees explain, none of them were ready for the change. This lack of preparation reveals another gap within the educational system.

For many people, it is easy to take for granted the existence of the digital native/immigrant dichotomy and assume that students are digital natives. At the same time, teachers are digital immigrants, as the following excerpt shows:

Collaboration between native digital students/teachers with knowledge about the pedagogical use of technological tools with digital immigrant teachers who showed interest in developing digital skills in record time. (Focus group, Teacher 7, September 29, 2020)

However, in many cases, this is a baseless assumption. During the first months in the ERT mode, the experience showed that both English TEs and their pupils lacked enough training to conduct virtual education. Indeed, the former reported having to struggle with designing or adapting activities, and many of the latter had difficulties trying to use the different programs, platforms, and web pages to develop class activities:

It was difficult for the students and for me to learn to use the technological tools better. (Second questionnaire, TE6, January 11, 2021)

Additionally, as in previous challenges, using technologies permanently brought some issues to both English TEs and trainees. In the case of the former, preparing the activities, giving feedback to the latter, and attending the synchronous sessions led to work overload. Therefore, extreme exhaustion, feelings of uncertainty, and anguish surfaced:

If it is considered that [the confinement] was something sudden and unknown, some emotional problems arose that somehow affected the academic processes. Sometimes feelings of uncertainty, doubts, and insecurity about skills arose. Added to this, the fatigue and stress generated by being connected for
$100 \%$ of the academic and professional activities without physical contact with people also contributed to the generation of negative emotions. (Second questionnaire, TE7, January 11, 2021)

It has been an especially complicated process since motivation is disappearing due to mediated education. Furthermore, it is intellectually exhausting to be in front of a computer all day and even in free time while working. All this together, in turn, generates physical fatigue. (Questionnaire, PST21, February 2, 2021)

Technology-mediated education has personally increased my past issues, such as anxiety, stress, and frustration. (Questionnaire, PST 12, January 27, 2021)

Despite this and other challenges run into by English TEs and students during the transition of face-to-face to the ERT mode, we must recognize the extraordinary efforts they made to go on. These efforts included changes in teaching strategies by English TEs to contribute to trainee teachers' educational process.

\section{Changes in the Strategies Used in Classes}

Undoubtedly, the transition from face-to-face classes to ERT mode required English TEs' strategies to change. To determine this change, it is necessary first to show some of those strategies that TES were using before the transition and then the ones used during the transition to ERT (see Table 2).

Based on TEs' answers in the questionnaire, the most common strategies used to be collaborative work, group discussions, presentations and lectures, ludic activities, ICT, classroom projects, role play, and reflection questions. Some PST agreed and explained which strategies their teachers used in classes:

In face-to-face classes, some teachers were quite creative. They made us create posters and present the subject before the class. They had debates, group discussions, and many other cooperative activities within the classroom. (Questionnaire, PST25, February 4, 2021)

Face-to-face classes used to be more dynamic. Most of my teachers were in charge of explaining the theory 
Table 2 Changes in Teaching Strategies and Tools

\begin{tabular}{lll}
\hline \multicolumn{1}{c}{ Teaching Strategies Before covid-19 } & Teaching Strategies During covid-19 & Tools Used During the Transition \\
\hline Collaborative Work & Use of a repository or LMs & Infographics \\
Group Discussion & Adaptation of Activities to Virtual & Interactive Books \\
Presentations and Lectures & Environments & Videos \\
Ludic Activities & Collaborative Work & Forums \\
Limited Ict Use & Group Discussion & Break-up Rooms \\
Classroom Projects & Presentations & Voice Threads \\
Role Plays & Unlimited Ict Use & Google Docs \\
Reflection Questions & & Meeting Rooms \\
& & WhatsApp Groups \\
& & Facebook \\
\hline
\end{tabular}

of the class and putting it into practice through meaningful activities for us. They made use of different resources and materials that will help to have a better understanding of the problems. (Questionnaire, PST 12, January 27, 2021)

Explain the topics on the board, bring teaching materials such as books, photocopies, slides, etc. These activities reinforce what is seen in class, make workgroups, put forward topics in class, and interact with our classmates. Most of the teachers have us work in groups. They taught through games. Reading in groups and giving our opinion or having discussions in class were the most common in most of my courses. (Questionnaire, PsT 14, January 27, 2021)

The excerpts above show that the TEs' strategies in face-to-face lessons were diverse and aimed at learning in a meaningful way, promoting interaction and reflection. Below we present the results of the exploration of pedagogical strategies and technological resources used to overcome the challenges mentioned in the previous section.

The first change found was the adaptation of what was planned for face-to-face to the ERT mode. One of the English TEs expressed it in the following way:

The changes made had more to do with the means used for teaching and access to information resources than with the nature of the strategies described above. Reflecting on this, the biggest challenge was finding the appropriate virtual means (platforms, applications, etc.) to carry out the sessions so that these strategies could continue to be present in the classes. (Second questionnaire, TE4, February 10, 2021)

As shown in the excerpt, the first action was simply to put the information that was designed for face-to-face classes in a repository or LMS in which it could be administered and delivered to PST. However, later on, TEs saw the need to redesign the activities they had planned and adapt them to virtual environments, as the following quote indicates:

The main changes occurred in the search for tools other than videoconferencing that allowed students to interact and contribute to different activities and provided one-way communication (teacher-students). The search involved verbal communication strategies and ways in which students could interact and contribute to the different activities with synchronous and asynchronous tools (forums, blogs, Google docs, meeting rooms, etc.). Another change occurred in the presentation of the materials. Formats such as videos, interactive books, and infographics were included to avoid that the teacher only presented the material. (Second questionnaire, TE7, February 11, 2021)

The above excerpt shows how English TEs needed to transform their academic discourses so that they were easy to adapt to digital media. This process required an effort from them, as they used to construct knowledge in the classroom, and now they were limited to virtual means. For example, 
as TE7 points out, it was necessary to transform the content of his subject area and adapt it to infographics, interactive books, videos, forums, etc.

PST highlight these same strategies as contributions to their learning process in those tough times of learning across the distance:

The teachers tried to find tools and solutions that would allow them to adapt the contents that had to do with this new modality. Most of the teachers told us about flexibility when it comes to assignments and assessments. You could see the effort made by several teachers so that the classes were not tedious or only the teacher was the one who spoke. Many of them adapted the technological tools to promote a real learning environment. (Questionnaire, PST5, January 27, 2021)

When virtual classes began, teachers had more resources. The activities continued to be similar except that it was through a computer. It was discussed in groups (in different rooms), a topic was presented, we recorded our analysis of a poem and uploaded it to Voicethread, we wrote diaries, the teacher shared the recorded class with all his students, etc. I think it was a great advantage in that regard, given that there were more resources available. (Questionnaire, PST25, February 4, 2021)

These efforts to address PST's needs were ongoing. The use of different web pages designed for collaborative work was essential in their learning. The level of involvement of PST was also evident since they went from being passive at the beginning of the transition to active when participating in the different activities and through the different websites proposed by their TE.

Additionally, social media were implemented as a strategy to increase interaction and improve communication between TES and PST. This is the second change that stands out within the process, as the following quotes indicate:

I created a WhatsApp group as an information strategy and didactic alternative, and I used Facebook groups with the same purpose. (Questionnaire, TE6)

Facebook was used by a teacher educator who claims that he communicated effectively with the students and sent them information about the class. (Focus group, Teacher 2, September 29, 2020)
Other TEs added that these strategies were practical even when they requested activities or when they had to evaluate PST:

WhatsApp has helped me a lot to communicate with them. It was what everyone had and the least complicated for them. Even the tool I used the most for oral reports with English 1 when they were individual.

(First questionnaire, TE2, October 13, 2020)

However, the use of these social media implied taking care not to go beyond the limits related to personal life and time:

Now the interaction is constant because we continue to communicate by email. I also opened a new account in WhatsApp Business with a different number than the personal one to interact with my students in real-time or when they need it but setting limits. (Second questionnaire, TE5, February 10, 2021)

Though, others allowed a closer approach by considering it necessary to pay attention to personal needs:

In addition to the strategies that were used (virtual classroom), other means of communication were opened even through social networks that were used more frequently. The interaction was not limited to encounters, but almost daily, the students communicated for consultations or questions of an academic and even personal nature with those students who presented difficulties. (Second questionnaire, TE7, February 11, 2021)

In short, social media use was a remarkable success during the transition; it made it possible to contact even those who had connection difficulties or did not have enough resources to stay connected to virtual classes and classrooms.

\section{Challenges for the Future}

After analyzing the changes that happened during the transition from face-to-face classes to ERT mode, some challenges remain. The first challenge is keeping updated with technology. As many of the TEs recognized, their technology skills were not as strong as this ERT mode required. Even after these first experiences in ERT mode, TES 
recognized that it is necessary to deepen the use of technology, web pages, and remote learning to boost learning in their classes:

We must learn and keep up with world changes (in terms of technology), that we must not put ourselves in negative positions, we cannot, but how can I do it. (Second questionnaire, TE2, February 9, 2021)

Both teacher educators and pre-service teachers must be constantly updated in the use of teaching tools and pedagogical strategies, and thus adaptability to change is a little easier. (Second questionnaire, TE5, February 10, 2021)

Nevertheless, English TEs and PST highlighted that they expected the university to provide more support in this respect:

It is important to have institutional support for the guidelines and policies delivered regarding the inclusion of virtual, blended, remote methodologies, etc. (Second questionnaire, TE7, February 11, 2021)

Train more students and teachers on ICTs, I am not very familiar with that topic (Questionnaire, PST22, February 4, 2021)

The university can teach teachers how to use different platforms. (Questionnaire, PST9, January 27, 2021)

These requests for more training in the use of ICTs could contribute to design strategies and activities that foster learning and professional development.

A second challenge for the future is boosting trainees' motivation, fostering autonomy, and enhancing interaction. Although this challenge is connected to the previous one, it is possible to strengthen education processes in all dimensions to understand virtual strategies and resources better. In terms of motivation, TEs suggested that they continue looking for alternatives to engage PST in classes and feel comfortable with their learning process.

It is essential to continue working to search for strategies to motivate and maintain pre-service teachers' interest in academic processes. (Second questionnaire, TE5, February 10, 2021)

Suppose the PSTs can motivate themselves in the right way. In that case, they will surely make a more significant effort to carry out the activities and find an alternative to continue learning independently. Also, as part of this challenge, TEs must do as this TE suggests:

It is necessary to innovate and promote spaces where the pre-service teacher has greater responsibility in their training processes, autonomous and independent learning strategies so that the academic processes do not depend $100 \%$ on the teacher. It is also necessary to strengthen communication strategies. Since there is a different mediation, the messages must be more direct and precise for effective communication. (Second questionnaire, TE7, February 11, 2021)

Finally, regarding interaction, TE2 expressed:

The interaction between teacher-student and stu-
dent-student is a fundamental element to improve in
technology-mediated classes. In the virtuality experi-
ence, this aspect is too complex to manage. (Second
questionnaire, TE2, February 9, 2021)

This quote shows how complex it can be to improve the interaction during the classes. However, it also shows that some TEs are willing to work for it since part of the teaching work is to analyze the difficulties and find strategies that fit the context. Nevertheless, there is still some uncertainty about whether it will be possible to achieve:

\begin{abstract}
A teacher educator expresses concern about how teachers can promote changes in the aspects we are reflecting on while we are on the other side of the screen. For example, what can we do to improve communication with those pre-service teachers who do not want to communicate with us? (Focus group, TE3, September 29, 2020)
\end{abstract}

These feelings are the norm, all the more so when we go through uncertain times.

\section{Discussion and Conclusions}

This case study aimed to explore the pedagogical strategies and technological resources used by TEs in a Foreign Language Teacher Education Program to overcome the challenges posed by the transition from face-to-face teaching to emergency remote teaching in times of the COVID-19 
pandemic. Three main categories emerged from the data analysis. Findings showed that TEs faced challenges early in the transition to ERT that led to rapid changes in their technology-mediated teaching practices and strategies; still, other challenges that arose from those changes continue.

One of the most critical challenges for TEs is related to the awareness of the PST's realities. Knowledge and understanding pose a challenge for TEs because they force them to go from the mere perception of reality to being part of it through a dialectical exercise involving PST personally through a computer screen. As Insuasty and Jaime-Osorio (2020) suggest, this "dialectical interaction between the English teacher and the sociocultural and educational environment" (p. 67) permeates teachers' roles, bringing about a transformation of teaching practices. For this case, the teacher's role changed because being exposed to a closer look at PST's reality in times of pandemic, a more profound reflection took place in, on, and for action (Schön, 1987; Hawkridge, 2000). These reflections led TEs to explore new practices derived from their trainees' feelings of frustration, sadness, and helplessness.

Another challenge faced by TEs and PSTs that remains for the future has to do with teachers' experience with online teaching. Although the tip of the teacher iceberg is blurred for PSTs when viewed from a black background screen (Malderez \& Bodóczky, 1999), findings show that even though TEs are familiar with the use of ICTs, they recognize that their knowledge was not and is not enough to keep PSTs genuinely connected to a virtual environment (Blake, 2008). Therefore, TEs must help each other save time and effort and assess their core beliefs to generate insights that serve as a foundation for their transformed practices. In fact, although the means of interaction such as Google Meet ${ }^{\circ}$ or Learning Management Systems were 'normalized' (Bax, 2003) in the times of COVID-19, TEs realized that online learning takes time.
The development of new and attractive activities and the evaluation of ready-made resources on the web requires that the TE be aware of PSTS' needs and prioritize learning, leading to professional development. For this, the TE must recognize that PSTs are not entirely digital-natives and that they require training to use technologies just like them. However, this training is not the TEs' sole responsibility; the university also offers spaces to learn about the proper use of technologies in education (Castañeda-Trujillo \& Rincón, 2018; Herrera, 2017).

Chambers and Bax (2006) argued that knowledge and skills, integration of curricula and software, and training development and support are merely some of the factors that can hinder CALL standardization, which simply reaffirms what we have found. It should not be forgotten that individual efforts to improve teacher-student interaction should be minimized and that TEs should assume a more critical role instead. Just as we seek activities for PSTs to work collaboratively, teachers must look for ways to work together and be "critical of the ways in which these virtual environments can be used and exploited effectively to enhance language learning." (Castañeda-Trujillo \& Cruz Arcila, 2012, p. 87). As the authors put forward, TEs could foster trainees' autonomy, collaboration, and interaction. Together, they would reflect and redefine how technologies are used, gradually integrating these processes into the educational project of the context in which they are immersed. In the words of De Zubiría (2020, para. 11), the responsibility of teachers is to know the new digital skills that will help them rethink education. They must guide parents in the new skills they will temporarily assume, evaluate training processes, and monitor each PST's academic and social-emotional development. We believe that TEs have already heard this call, however, this is only the beginning of the journey.

Finally, evidence shows that TEs' teaching strategies changed despite time constraints during ERT conditions using reflection derived from this group's well-founded research practices. That was a direct 
cause for PSTs to become more involved in the activities they prepared. Rather than an imposed process, there was some sort of negotiation or mediation between the more digital-savvy PSTS and TEs. They showed a willingness to learn from them during the transition time. Social media integration was recognized as the most powerful tool to improve communication with PSTs, especially with those who had little or no access to the Internet, who could only attend their lessons via a smartphone. Social networks and media evoke some of the four metaphors proposed by Reinhardt (2020): Windows, mirrors, portals, and playgrounds. Until now, they have served as a window to look at PSTs' realities, as mirrors to see our own reality, and as doors that have led us to different paths of trying and failing or achieving. Following Alavi and Leidner's (2001) call, we believe it is time to bring together all the research we have conducted on this topic to see how technology can enhance learning.

\section{Limitations of the Study and Future Research}

This study's major restrictions and drawbacks are related to the sample size and the conditions under which the data were collected. Unfortunately, due to the limited interaction with PSTs, their participation in the focus group was reduced. In addition, given that the conditions of ERT in this particular context were limited (four months), time constraints might have affected the collection of a greater amount of information; nonetheless, the quality of the data analysis process was not affected. Therefore, we think that future research should consider the use of narrative interviews since an in-depth look at English TES' and PSTS' personal experiences could provide a broader understanding of the changes and challenges lived during confinement.

We believe that further research on the matter could focus on a deeper exploration of the interaction of factors such as context, psychological processes, technological capacity, and instructional strategies. It is time that ERT and all the informed teaching experience in times of COVID-19 help us reaffirm our role as thoughtful researchers and practitioners. Similarly, it is crucial to lay the foundations for transforming the educational system by consolidating and systematizing the TEs' practices that have been changing and strengthening within this adverse context of the pandemic.

\section{References}

Alavi, M. \& Leidner, D. E. (2001). Research commentary: Technology-Mediated learning-A call for greater depth and breadth of research. Information Systems Research 12(1), 1-10. https://doi.org/10.1287/ isre.12.1.1.9720

Barbour, M. K., Labonte, R., Kelly, K., Hodges, C., Moore, S., Lockee, B., \& Trust,T. (2020). Understanding pandemic pedagogy: Differences between emergency remote, remote, and online teaching. A special report of the state of the nation: K-12 E-learning in Canada project. https://doi.org/10.13140/ RG.2.2.31848.70401

Barson J. \& Debski R. (1996) Calling back CALL: Technology in the service of foreign language learning based on creativity, contingency, and goal-oriented activity. In Warschauer M. (ed.) Telecollaboration in foreign language learning (pp. 49-68). University of Hawai'i, Second Language Teaching and Curriculum Center.

Bax, S. (2003). CALL-past, present and future. System, 31(1), 13-28. https://doi.org/10.1016/ S0346-251X(02)00071-4

Blake, R. (2008). Brave new digital classroom. Technology and foreign language learning. Washington University Press.

Bozkurt, A. \& Sharma, R. C. (2020). Emergency remote teaching in a time of global crisis due to Corona Virus pandemic [Editorial]. Asian Journal of Distance Education, 15(1), i-iv. https://doi.org/10.5281/ zenodo. 3778083

Castañeda-Trujillo, J. E. \& Cruz Arcila, F. (2012). Through teachers' eyes: the use of virtual classrooms in ELT. How Journal, 19(1), 76-92. https://www.howjournalcolombia.org/index.php/how/article/view/39

Castañeda-Trujillo, J. E. \& Rincón, L. (2018). Foreign language teachers' education: Challenges and implications in integrating technologies of information and communication. In H. Castañeda-Peña (Ed.), 
Technology in ELT: Achievements and challenges for ELT development (pp. 75-94). Universidad Distrital Francisco José de Caldas.

Chambers, A. \& Bax, S. (2006). Making CALL work: Towards normalization. System, 34(1). 465-479. https://doi.org/10.1016/j.system.2006.08.001

Colegio Nueva Granada (CNG) (2020). Bogotá Distance Learning Hub - Información del Plan de Aprendizaje a Distancia: Distance Learning Plan. https:// libguides.cng.edu/c.php?g=1007782

De Zubiría, J. (2020). La educación en tiempos de cuarentena. Semana, Op-Ed. https://www.semana.com/ opinion/articulo/la-educacion-en-tiempos-de-cuarentena-columna-de-julian-de-zubiria/661969

Duff, P. A. (2008). Case study research in applied linguistics. Lawrence Erlbaum.

Fierro, C., Fortoul, B., \& Rosas, L. (1999). Transformando la práctica docente: una propuesta basada en la investigación-acción [Transforming teaching practice: A proposal based on action research]. Paidós Mexicana.

Flick, U. (2009). An introduction to qualitative research (4 $4^{\text {th }}$ ed.). Sage Publications Ltd.

Golden, C. (2020, March 23). Remoteteaching: The glass halffull.EDUCAUSE Review. https://er.educause.edu/ blogs/2020/3/remote-teaching-the-glass-half-full

Hawkridge, D. (2000). A brief history of critical reflection. In h801, Study Guide, section 2, part 1, The Open University, Milton Keynes, UK.

Herrera, L. (2017). Impact of implementing a virtual learning environment (VLE) in the EFL classroom. Íkala, Revista de Lenguaje y Cultura, 22(3), 479-498. https://doi.org/10.17533/udea.ikala.v22n03a07

Hodges, C., Moore, S., Lockee, B., Trust, T., and Bond, A. (2020). The difference between emergency remote teaching and online learning. EDUCAUSE Review. March 27th, 2020. https://er.educause.edu/ articles $/ 2020 / 3 /$ the-difference-between-emergency-remote-teaching-and-online-learning

Huberman, S. (1999). Cómo se forman los capacitadores: arte y saberes de su profesión [How trainers are trained: art and knowledge of their profession]. Paidós.

Insuasty, E. A., \& Jaime-Osorio, M. F. (2020). Transforming pedagogical practices through collaborative work. Profile: Issues in Teachers' Professional Development, 22(2), 65-78. https://doi.org/10.15446/profile. v22n2.80289
Kincheloe, J. L. (2003). Teachers as researchers: Qualitative inquiry as apath to empowerment $\left(2^{\text {nd }} \mathrm{Ed}\right.$.). Routledge Falmer. https://doi.org/10.4324/9780203497319

Mae-Toquero, C. (2021). Experimento de educación remota de emergencia en medio de la pandemia de COVID-19 en instituciones de aprendizaje en Filipinas. International Journal of Educational Research and Innovation (IJERI), (15), 162-176. https://doi. org/10.46661/ijeri.5113

Malderez, A. \& Bodóczky, C. (1999). Mentor courses: A resource book for trainer-trainers. Cambridge University Press.

Merriam, S., \& Tisdell, E. J. (2016). Qualitative research: A guide to design and implementation ( $4^{\text {th }} \mathrm{Ed}$.). Jossey-Bass.

Olasile Babatunde, A. \& Emrah, S. (2020). covid-19 pandemic and online learning: The challenges and opportunities. Interactive Learning Environments. https://doi.org/10.1080/10494820.2020.1813180

Reinhardt, J. (2020). Metaphors for social media-enhanced foreign language teaching and learning. Foreign Language Annals, 53, 234-242. https://doi. org/10.1111/flan. 12462

Sarkar, S. (2012). The role of information and communication technology (ICT) in higher education for the $21^{\text {st }}$ century. The Science Probe, 1(1), 30-40.

Schön, D. A. (1987). Jossey-Bass higher education series. Educating the reflective practitioner: Toward a new design for teaching and learning in the professions. Jossey-Bass.

Tafazoli, D. \& Golshan, N. (2014). Review of computer-assisted language learning: History, merits \& barriers. International Journal of Language and Linguistics, 2(4), 32-38. https://doi.org/10.11648/j. ijll.s.2014020501.15

Vasilachis de Gialdino, I. (2009). Los fundamentos ontológicos y epistemológicos de la investigación cualitativa. Forum Qualitative Sozialforschung / Forum: Qualitative Social Research, 10(2), 1-26. http://nbn-resolving.de/ urn:nbn:de:0114-fqs0902307

Vlachopoulos, D. (2020). covid-19: Threat or opportunity for online education? Higher Learning Research Communications 10(1), 2. https://doi. org/10.18870/hlrc.v10i1.1179

Warschauer, M. (1996). Computer-assisted language learning: an introduction. In: Fotos, S. (Ed.), Multimedia Language Teaching (pp. 3-20). Logos. 
Warschauer, M. (2000). CALL for the $21^{\text {st }}$ Century. LATEFL and ESADE Conference, July $2^{\text {nd }}, 2000$, Barcelona, Spain.

Warschauer, M. \& Healey, D. (1998). Computers and language learning: an overview. Language Teaching,
31, 57-71. https://doi.org/10.1017/ S0261444800012970

Yin, R. K. (2002). Case study research: Design and Methods. Sage Publications.

How to cite this article: Castañeda-Trujillo, J. E., \& Jaime-Osorio, M. F. (2021). Pedagogical strategies used by English teacher educators to overcome the challenges posed by emergency remote teaching during the Covid-19 pandemic. Íkala, Revista de Lenguaje y Cultura, 26(3), 697-713. https://doi. org/10.17533/udea.ikala/v26n3a12 
